\title{
The impact of public debt on economic growth: an empirical study of Mexico (1994-2016)
}

\author{
Jesús Vaca Medina, Gustavo Vaca Medina \\ and César Omar Mora Pérez
}

\begin{abstract}
Following on from recent literature on the same subject, this paper analyses the impact of public debt on economic growth in Mexico between 1994 and 2016, against a global macroeconomic backdrop of sharp rises in public sector debt indicators, owing to expansionary fiscal strategies adopted after the 2007-2008 crisis. The main objectives of this study are to determine whether the relationship between these two variables has followed a non-linear path in the form of an inverted " $U$ ", and to find the threshold beyond which increases in debt generate marginal decreases in growth. Using a dynamic model, a non-linear inverted $U$-shaped relationship is demonstrated, and the threshold in the debt-to-GDP ratio is found to be $27 \%$.
\end{abstract}

\section{Keywords}

Economic conditions, economic growth, econometric models, gross domestic product, macroeconomics, Mexico, public debt

\section{JEL classification}

E62; H63; O54

\section{Authors}

Jesús Vaca Medina is a lecturer with the Department of Administration of the Centre for Administrative and Economic Sciences of the University of Guadalajara, Mexico. Email: jvacamedina@gmail.com.

Gustavo Vaca Medina is a lecturer with the Department of Administration of the Centre for Administrative and Economic Sciences of the University of Guadalajara, Mexico. Email: gvacam58@gmail.com.

César Omar Mora Pérez is a teaching fellow with the Department of Administration of the Centre for Administrative and Economic Sciences of the University of Guadalajara, Mexico. Email: cesar.mora@cucea.udg.mx. 


\section{Introduction}

Compared to the rest of the twentieth century, from the late 1970s to the early 1990 s economic and social conditions were dismal in Mexico and almost all the other Latin American countries. In some countries of the region, the key factor that drove them into this painful period was the establishment of dictatorships, while in others it was the debt crisis.

In Mexico, for instance, between 1982 and 1986 production was stagnant, while on average no less than $6 \%$ of gross domestic product (GDP) was transferred to external creditors (van Wijnbergen, 1991a). Faced with imminent economic collapse, the restraint measures implemented under the Brady Plan ${ }^{1}$ helped Mexico move forward, investors' confidence was restored and capital flight was avoided. This generated greater macroeconomic stability and the right conditions for a return to the economic growth that Mexico had seen over the 30-40 years prior to the crisis.

Debt restructuring contributed to the return to growth in the second half of 1989. However, the 1994 debt crisis hit Mexico particularly hard, mainly because a significant portion of government payable bonds were denominated in dollars, in addition to the mismanagement of public finances and the unstable global economic environment. Once again on the verge of declaring a moratorium, this time it was the United States that created a rescue plan to prevent a Mexican default.

Despite the complicated economic situation and the difficulties caused by the sudden and forced opening of trade, Mexico was able to rein in its debt problems, as reflected in its levels of public debt, which were contained below the threshold of $18 \%{ }^{2}$ of GDP for the rest of the 1990 s and almost the entire first decade of the twenty-first century. During this period, under the New Consensus Macroeconomics (NCM) model that governed economic policy around the world, fiscal policy was limited to being a mere automatic stabilizer, with no active role in countries' economies.

However, the global financial crisis of 2007-2008 caused an imbalance in the public finances of the vast majority of countries, both developed and developing, around the world. ${ }^{3}$ This was mainly a result of the expansionary strategies adopted by governments to boost their economies through public spending and investment, which had generated large fiscal deficits. ${ }^{4}$ Consequently, debt-to-GDP ratios rose rapidly, hitting levels not seen since the post-war period, when the welfare state model prevailed.

Mexico was not immune to this global trend, and was also forced to abandon its previously stable debt levels, in order to overcome the ravages of the crisis. From 1994 to 2008 the country's debt-to-GDP ratio averaged $16.83 \%$, and its debt was even reduced by an average of $2.74 \%$ a year, bringing it down from $22.02 \%$ in 1995 to $14.74 \%$ in 2008. However, from 2009 to 2016, the debt-to-GDP ratio ballooned by $14.12 \%$ per year, leaving the average for the period at $31.58 \%$. It jumped from $14.74 \%$ in 2008 to $25.52 \%$ in 2009, and in 2016 it reached $37.49 \%$. Figure 1 shows the evolution of the debt-to-GDP ratio in Mexico.

This pattern, which was seen in Mexico and many other parts of the world, together with over-optimism about fiscal expansion owing to a revival in Keynesian ideas, generated concern among some academics over the impact that high debt ratios have, or could have, on economic growth.

\footnotetext{
1 The Brady Plan consisted of restructuring Latin American developing countries' debt held by commercial banks. Through the extension of terms, grace periods and greater ease of payment, the aim was to reduce the balance owed and generate a higher level of productive investment that would translate into growth and, subsequently, greater capacity to pay. For a detailed analysis of this plan and the benefits it brought to the Mexican economy, see van Wijnbergen (1991a and 1991b).

2 For the purposes of this study, the debt-to-GDP ratio is calculated on the basis of the net public sector debt figures of the Bank of Mexico, deflated by the GDP deflator, with 2008 as the base year. GDP data for Mexico can be consulted at [online] https:// www.inegi.org.mx/sistemas/bie/.

3 For example, in Iceland, Ireland, Spain, the United Kingdom and the United States, the average debt-to-GDP ratio increased by about 75\% between 2007 and 2009 (Reinhart and Rogoff, 2010).

4 In the eurozone, the fiscal deficit increased rapidly from 0.7\% of GDP in 2007 to 6\% of GDP in 2010 (Checherita-Westphal and Rother, 2012).
} 
Figure 1

Mexico: public debt as a proportion of GDP, 1994-2016

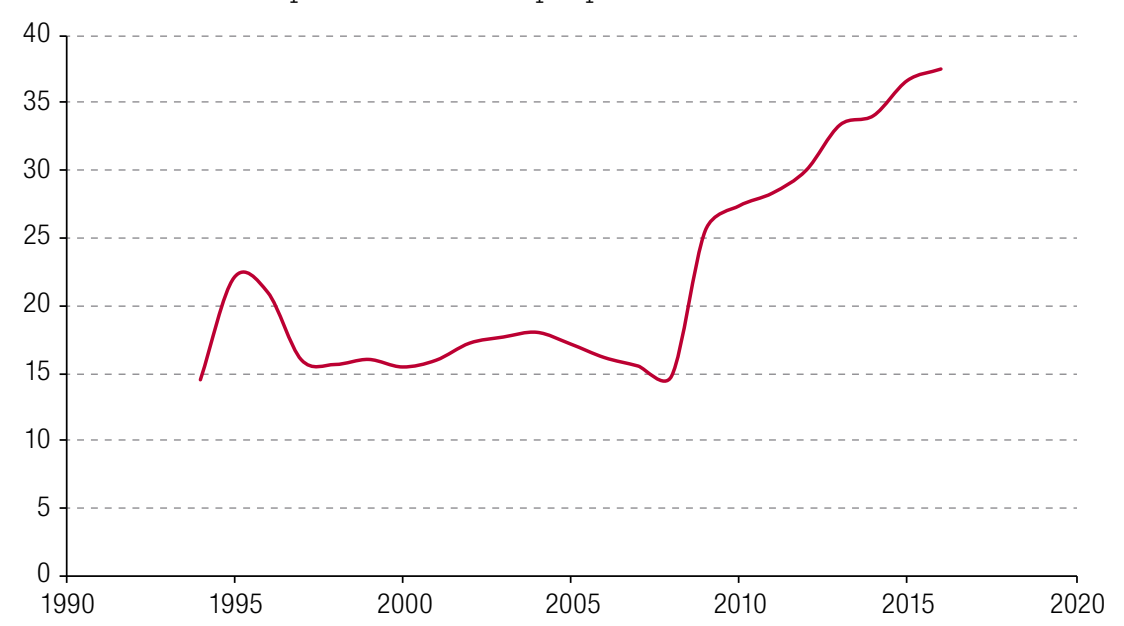

Source: Prepared by the authors, on the basis of data from the National Institute of Statistics and Geography (INEGI).

Existing literature suggests that debt has a non-linear and inverted U-shaped relation with growth: public debt initially has a positive impact on the economy, since it can boost aggregate demand through consumption, as well as financing activities and productive investments with private resources that would otherwise not be able to be carried out. Nevertheless, there is a point beyond which debt has a negative effect on marginal growth, since speculation arises over governments' ability to pay and capital begins to migrate, seeking projects elsewhere, thus reducing investment and stalling growth in any economy.

It is for this reason that, in the current context, a study of the relationship between public debt and growth in Mexico is of great importance. The aim of this document is to examine the impact that debt has had on the growth in the country, to verify whether a U-shaped curve exists and, if it does, to use econometric tools to determine the threshold in the ratio beyond which debt has a negative marginal impact on the economy.

It is true that, compared to other countries, ${ }^{5}$ Mexico's debt figures do not put the economy at risk or herald an imminent crisis. Nevertheless, if nothing is done and the debt-to-GDP ratio is allowed to continue to grow at its current rate for several more years, it will only be a matter of time before we witness serious instability and recessions, with a weakened State that has little capacity to intervene.

Although several studies have attempted to understand and explain this relationship, the average range for the inflection point in the inverted $U$ can be said to be between $30 \%$ and $50 \%$ of debt to GDP. These figures suggest that now is an opportune moment to address the issue in Mexico, since, as can be seen in figure 1, the country's debt-to-GDP ratio was just under 38\% in 2016. In addition, as indicated by Rojas (2017), the financial services company Standard \& Poor's assumes a high probability that Mexico's public debt will increase, in view of the economic policy packages it has adopted in recent years.

The rest of this document is structured as follows: section II examines the literature and the academic and political discussions of recent years on this controversial topic. Section III describes and justifies the data and variables used in the econometric model, and the methodology used. Section IV presents the results of the model and offers some policy suggestions to address the current situation. Lastly, the conclusions are set out in section V.

\footnotetext{
5 According to San Isidoro (2017), Japan topped the list of the most indebted countries in terms of debt-to-GDP ratio, with 237\%, followed by Greece with 181\%. The United States was in sixteenth position with 105\%, while China ranked one hundred and sixth with a ratio of $42 \%$.
} 


\section{Literature review}

\section{The relationship between public debt and growth}

Literature on the impact of public debt on economic growth is scarce and the bulk of the research work dates from the 2010s, perhaps due to the substantial increase in fiscal deficits around the world after the 2007-2008 crisis. Of those papers that were published prior to 2010, the most notable are Pattillo, Poirson and Ricci (2002) and van Wijnbergen (1991a).

The dramatic increase in fiscal deficits after the 2007-2008 crisis was a result of a paradigm shift in the developed world, which was later repeated in many developing countries. After the Second World War, the Keynesian model and the welfare state gathered noticeable momentum, and the public sector played an important role in countries' economic activity. At that time, public spending was therefore an essential tool for sustaining growth, owing to its effects on aggregate demand. This model was accompanied by very strong economic growth in several countries around the world, and the post-war period is even remembered in Western Europe as the "glorious thirties".

Some economies that had previously lagged behind the major economic powers, namely the United States and the United Kingdom, began to gain ground on them after the Second World War. Therefore, in an effort to retake the helm of the world economy, the major economic powers decided to implement a new neoliberal economic model, which was then adopted by a number of other countries. This decision is still being questioned to this day by some of those countries, as growth rates slumped after the model was implemented. The outcomes of this change included an opening up to trade, a withdrawal of the State from economic activity and the adoption of NCM.

The NCM model revolutionized economic policy, marking a move away from the Keynesian model of effective aggregate demand to one of inflation targets and flexible exchange rates in which the short-term interest rate was an essential monetary policy instrument (Arestis, 2009). Conversely, fiscal policy was discredited and dismissed as inefficient, with its role limited to that of a mere stabilizer of the economy. In other words, NCM assume a direct relationship between aggregate demand and interest rates.

However, in recent years, despite low interest rates in some robust economies that follow the NCM model, the developed world has not been able to recover from ongoing crises or return to the growth rates of past decades. Several countries are therefore looking once again to fiscal policy to drive aggregate demand and, consequently, economic growth.

This is the paradigm shift that has led to an increase in States' fiscal deficits and debt levels in recent years. This in turn has provoked an in-depth discussion on the effects of debt on economic growth, a discussion that seems far from over.

In theoretical literature, there is a diversity of positions regarding this phenomenon: some assume a negative relationship between debt and per capita economic growth, while several other endogenous growth models show that debt has a positive impact on growth, provided that the resources obtained from third parties are used to finance productive public capital, which is primarily the case in developing countries.

The dominant theory today is that debt has a negative impact on growth. ECLAC (2018) identifies three transmission channels that justify the conclusion that the current economic model and NCM have discredited the use of fiscal policy and the power of fiscal deficits to boost growth.

The first transmission channel, and perhaps the one most often invoked, is the concept of Ricardian equivalence, which assumes that a rise in public spending financed by debt will sooner or later force the government to raise taxes to pay it down. It is thought that this will lead economic agents to save the extra income generated by the increase in public spending since they will have to pay more taxes in future. As a result, a fiscal deficit does not lead to greater aggregate demand. 
The second transmission channel is higher inflation and reduced purchasing power driven by increased public spending, because it stimulates consumption but not productivity. Accordingly, overall aggregate demand would fall. In other words, the transfer of resources from the private to the public sector acts as a tax, since the transfer takes the form of a price increase, decreasing the purchasing power of economic agents.

Lastly, the third transmission mechanism is "crowding out", which assumes that indebtedness hurts private investment, due to the resulting movements in the capital market. Interest rates rise, due to competition for resources among the public, private and external sectors. Higher interest rates discourage investment and cause the exchange rate to appreciate, with a combined impact on aggregate demand that almost always outweighs the economic incentive generated through the fiscal deficit. This rationale is advocated by those who consider that a crisis can be postponed, but not averted.

According to Arestis (2009), the main consequence of NCM is a narrow interpretation of fiscal policy as an instrument that should only be concerned with balancing government expenditure and taxation, downgrading its importance as an active instrument of economic policy. For this reason, the defenders of this model consider the public deficit strategy to be entirely inefficient.

In contrast, there are advocates of the opposite position, which is to say that there is a positive relationship between the public deficit and economic growth. Among them is Krugman (2009), who argues that an increase in government spending automatically raises future debt, but not by an equal amount, because higher spending raises GDP, it leads to higher revenue, which offsets a significant fraction of the initial outlay. Krugman (2009) suggests that the actual cost of fiscal stimulus is approximately $60 \%$, since the other $40 \%$ is offset by growth in aggregate demand.

Furthermore, in the same study, Krugman (2009) argues that today, in a world dominated by expectations, the main determinant of private investment is the state of the economy. This means that anything that improves the state of the national economy, including fiscal stimulus, leads to more investment and hence raises the economy's future potential. It is for this reason that deficit spending does not lead to crowding out, but rather to crowding in. He therefore concludes that the worst thing that could be done for future generations is not to run sufficiently large deficits now.

Lastly, Krugman (2009) formulates this proposal within a developed economy immersed in a liquidity trap, where low interest rates result in monetary policy that is unable to encourage private investment. He therefore concludes that, upon emerging from the liquidity trap through this strategy, the normal rules of economic prudence will reassert themselves. That is to say, the fiscal deficit must be used at certain times to boost aggregate demand, but it should not become an established doctrine since it can generate serious problems for economies.

The concept of crowding in, which was first described by Aschauer (1989a and 1989b), assumes that public spending has a significant positive impact on private investment by increasing productivity, but only if public funds are earmarked for public investment and capital expenditure, meaning spending on areas such as research, roads, transport, infrastructure and energy projects. Hatano (2010) provides empirical evidence that supports this position.

With regard to the relationship between public debt and economic growth, the current consensus is that both the concepts of crowding in and crowding out have some impact, thus the relationship can be illustrated by a Laffer curve or, in other words, it follows an inverted U-shaped trend. In countries with low levels of indebtedness, the resources generate a marginal positive impact on the economy due to their impact on aggregate demand, until they pass the threshold beyond which their effects produce a negative marginal trend, mainly owing to expectations regarding debt sustainability and capital market problems.

In this case, if debt resources are allocated to capital expenditure instead of social spending, this non-linear relationship is not modified, but they can alter the slope of the curves and displace the point of inflection in the curves, making the debt more productive and allowing it to stimulate economic growth. 
Among the first empirical references to this Laffer curve or inverted U-curve between public debt and economic growth were made by Pattillo, Poirson and Ricci (2002), who undertook a study of 93 developing countries over the period 1969-1998 and found that the point at which the overall contribution of debt to growth appears to become negative is between $160 \%$ and $170 \%$ of exports, and between $35 \%$ and $40 \%$ of GDP. They therefore concluded that the main determinant of this inflection point and of growth differences across countries is total factor productivity rather than factor accumulation; hence, the inflection point could change over time or among different countries, depending on how resources obtained through borrowing are allocated.

Although it is a very complete study, both in terms of data (number of countries and years) and in methodological tools, its publication did not have much impact on the academic or political spheres, perhaps due to the predominant feeling of economic calm and stability in the early 2000s.

However, after the global crisis, the ground-breaking article by Reinhart and Rogoff (2010) used descriptive statistics to show that countries with a debt-to-GDP ratio above $90 \%$ recorded slower growth than countries with lower ratios. Even among advanced economies, in the period 1946-2009, a debt-to-GDP ratio of $90 \%$ was correlated with a $0.1 \%$ reduction in growth.

Although this work was very similar to that of Pattillo, Poirson and Ricci (2002), and even had fewer methodological requirements, it had an overwhelming impact on society. According to Krugman (2013), the Reinhart and Rogoff paper may have had the more immediate influence on public debate than any previous paper in the history of economics. This was because it was published in the midst of the debate over whether Keynesian expansion or neoclassical fiscal consolidation was the best government response to the financial crisis. The conclusions of Reinhart and Rogoff led to the adoption of numerous consolidation policies around the world (Domínguez, 2013).

While those conclusions were still influencing the economic policy strategies of many countries, Herndon, Ash and Pollin (2013) identified methodological flaws in the work of Reinhart and Rogoff (2010). Correcting for errors and omissions, they show that the debt-to-GDP ratio threshold was above $120 \%$, much higher than the figure of $90 \%$ cited by Reinhart and Rogoff.

This new evidence bolstered the Keynesian view that spending financed with debt remained the most effective instrument available to combat the mass unemployment caused by recessions and severe economic crises. Therefore, Herndon, Ash and Pollin (2013) invited the leaders of the United States and Europe to reconsider the austerity policies they had implemented in the light of Reinhart and Rogoff's findings. ${ }^{6}$

A decisive point made by Herndon, Ash and Pollin (2013) is that econometrics can be used to study the inflection point beyond which the marginal contributions of debt to growth are negative. In this regard, they find that the threshold is debt-to-GDP ratios between $0 \%$ and $30 \%$.

In addition to Reinhart and Rogoff (2010) and Herndon, Ash and Pollin (2013), which are considered seminal works in the study of the effects of debt on growth, other authors also took an interest in the subject and made significant progress in expanding on the causal relationship between these two variables. For example, Cecchetti, Mohanty and Zampolli (2011) find an inverted U-shaped relationship for their sample of 18 advanced economies belonging to the Organization for Economic Cooperation and Development (OECD). The threshold they identify is a debt-to-GDP ratio of $84 \%$.

Cecchetti, Mohanty and Zampolli (2011) are convinced that debt is a crucial part of the economic system, since, without it, economies cannot grow, and macroeconomic volatility would also be greater than desirable. Also, if it were not for debt, countries would be poor and would surely remain so for a long time. However, when debt reaches high levels it becomes very dangerous because it generates systemic risk, raises real volatility and increases financial fragility in the country, reducing average growth and increasing the likelihood of a default. Although debt is beneficial for growth, governments' ability to

6 For further details of the discussion raised by Reinhart and Rogoff (2010) and Herndon, Ash and Pollin (2013), see Domínguez (2013). 
borrow is not unlimited. When private investors consider debt levels to be high and there is uncertainty over governments' fiscal capacity to repay it and to maintain macroeconomic stability, growth may plummet and governments' capacity to intervene will become very limited.

Meanwhile, in their study of 12 eurozone countries over 40 years, Checherita-Westphal and Rother (2012) find a non-linear relationship between debt and growth and a threshold of between $90 \%$ and $100 \%$ beyond which debt has a negative impact on the economy.

Égert (2015) makes one of the most recent and important contributions to this discussion, noting that finding a negative non-linear relationship between the public debt-to-GDP ratio and economic growth is extremely difficult and is sensitive to data coverage, meaning that the correlation is not as obvious as it may seem. However, using formal econometric testing, he finds that in the cases in which an inverted $U$-shape can be detected in the relationship between growth and debt, negative marginal correlation occurs at levels between $20 \%$ to 60\% of GDP. According to Égert, recent empirical evidence suggests that the reason for this is that the multiplier on public investment may be large for countries with low public debt ratios. His results also suggest that the threshold may be found at such levels because high-return public investment opportunities may exist at low levels of public infrastructure and debt.

Based on this information, it can be concluded that public capital expenditure does have a positive effect on economic growth with a multiplier greater than social spending, in accordance with the Golden Rule of contemporary economic theory, but that this ability it is not infinite. Therefore, provided that capital spending represents a larger proportion of total spending than social spending, the non-linear relationship will not change. Nonetheless, the positive slope of the inverted U-curve can change, and the inflection point can shift, allowing countries to have higher levels of productive indebtedness and, therefore, greater opportunities for growth. The calculation of the multipliers of social spending and capital spending in Mexico will be left for future research, to further this discussion.

The aforementioned literature make it clear that the debate on the scope of fiscal policy in today's economy is far from over: public debt and the Keynesian multiplier have appeared as considerations in new fiscal policy, as opposed to the rules of NCM established a few years ago.

Lastly, it should be borne in mind that the study of the effects of debt on growth support the impassioned debate over fiscal expansion versus fiscal consolidation, which has become more heated as a result of higher public spending policies adopted after the financial crisis of 2007-2008.

In this regard, Roeger and Veld (2013) seek to adopt a more neutral stance and analyse both the advantages and the disadvantages of each of these strategies. For example, they set out the arguments that when countries have been hit by external adverse shocks - as is currently the case, following the global financial crash - fiscal consolidation and austerity worsens the demand shortfall in the economy, while non-consolidation can have the same or even worse consequences for countries with high debt levels, as a result of the potential costs of higher debt premiums and risk of sovereign default.

Despite the intense discussions and the array of results and conclusions, it is an inescapable fact that the fiscal strategies adopted by governments to stimulate economic activity today will have a cost of potentially lower growth in the future. If this were not the case, as Domínguez (2013) asks, why not use expansionary fiscal policies indefinitely?

\section{Public debt and economic growth in Mexico}

With the notable exception of Pattillo, Poirson and Ricci (who used a panel of 93 developing economies), both empirical studies and the macroeconomic debate on the relationship between debt and economic growth have focused almost exclusively on developed countries, meaning that the literature fails to provide up-to-date analysis of the situation in developing economies, such as those in Latin America. 
This is reflected in the case of Mexico by the fact that literature on this subject is very scarce: only Sánchez-Juárez and García-Almada (2016) address this discussion. In their study, they determine that the growing debt of Mexico's subnational governments has promoted an increase in public investment, and with it, the economic growth of the states. However, although they find a positive correlation, they stress that attention must be paid to the trajectory of states' debt levels in order to avoid the tipping point beyond which growth would be negatively affected.

This again substantiates the economic precept of incurring debt exclusively for public investment or capital expenditure, given that the multiplier effect they have on growth is greater than that of social spending. However, Sánchez-Juárez and García-Almada (2016) also suggest a non-linear trend and assume that debt can have negative effects on the functioning of economies.

The reason given by Sánchez-Juárez and García-Almada (2016) for studying this relationship at the level of the Mexican states is that the volume of national debt has not yet reached a level that gives cause for concern or that threatens macroeconomic stability and investors' expectations. Therefore, they do not consider national debt to represent a problem that requires analysis.

Unlike Sánchez-Juárez and García-Almada (2016), based on the empirical results of the aforementioned documents, in this study the view is taken that Mexico's current debt levels and its debt trends of recent years make the subject worthy of examination. Such a study will provide information to help clarify a relationship between variables that remains very diffuse. This study is also important given the latent potential in Mexico's economy, where interest rates are much higher than the rate of economic growth, increasing the possibility of an explosive increase in the debt-to-GDP ratio, with severe economic repercussions.

These conditions exist in a context - following the global financial crisis - in which fiscal policy has been given the role of stabilizing the economy. However, in Mexico, as in much of Latin America, the trend in fiscal policy has been procyclical, which has deepened cycles instead of softening them. But in times of crisis, faced with the lack of automatic stabilizers, governments have fallen into a debt trap to finance unproductive spending, with the aim of boosting aggregate demand in the short term, resulting in a persistent public deficit.

Moreover, according to ECLAC (2018), there is a tendency in the region, and also in Mexico, to increase public spending, but with a notable preference for social spending and a constant reduction in levels of capital expenditure. For example, according to data from Durán (2018) and based on the Public Finance Studies Centre of the Chamber of Deputies, since 2006 the trend in Mexico has been to increase current spending and reduce private investment. Indeed, the latter declined from $3.7 \%$ of GDP in 2015 to $2.6 \%$ in 2017.

According to Albarrán (2017), a report by the Federal Superior Audit Office (ASF) of Mexico shows that physical investment shrank from $20.3 \%$ of the federal government's budgeted spending in 2010 to $15.9 \%$ in 2016, meaning that on average such investment declined by $1.1 \%$ a year in real terms over the period. In addition, between 2000 and 2016, public spending has grown twice as fast as the economy (4.4\% versus $2.2 \%)$. If only the period following the financial crisis is taken, this figure becomes more critical: average annual economic growth of $2.05 \%$ versus average annual growth in net debt (deflated by the GDP deflator) of $13.81 \%$. In addition, the ASF report states that education spending is below the average for the OECD countries, and that health spending is below the level recommended by the Pan American Health Organization.

We can therefore see that public spending does not contribute greatly to economic growth in Mexico, because historically capital spending has been very low, and it remains so, even declining in some periods of the twenty-first century. In addition, Albarrán (2017) asserts that public debt resources have been used to finance public pensions, federal contributions to regional and local budgets, and financial costs, expenditures that are far from being productive. 
Moreover, Mexican public spending shows procyclical behaviour: it increases when the economy is expanding, but does not decrease proportionally when the economy is in recession. As a result, persistent budget deficits have been accumulated, along with growing public debt. This is why, like Mexico, other countries of the region have suffered problems of over-indebtedness in recent years, which they have attempted to solve with fiscal responsibility laws.

\section{Description of the model}

The aim of this document is to analyse the impact of public debt on economic growth in Mexico, and specifically to determine whether the relationship between these two variables forms an inverted "U". If such a non-linear relationship is found, the aim is also to identify the inflection point in the curve. The study period is 1994-2016, due to the availability and homogeneity of the data that the National Institute of Statistics and Geography (INEGI) has for that interval.

The hypothesis, based on the theoretical and empirical evidence outlined above, is that there is a Laffer curve effect between debt and growth. In addition, the inflection point of the curve is between $20 \%$ and $60 \%$ of the debt-to-GDP ratio, as calculated by Égert (2015).

Through a basic statistical exercise, it was determined that the coefficient of correlation between the variables of per capita production and the debt-to-GDP ratio was 0.63 , so the two show a moderate linear association in their historical trends.

To justify a quadratic model, we must demonstrate the potential non-linear relationship between the two variables. To this end, in figure 2 the horizontal scale shows the debt-to-GDP ratios and the vertical scale shows growth rates in per capita GDP. There is a clear non-linear relationship that supports the inverted U-curve hypothesis, although with an imperfect shape, due to a very steep slope in the positive part with debt ratios lower than approximately $20 \%$, and a gentler slope in the negative part once the debt ratio passes $20 \%-25 \%$.

Figure 2

Mexico: relationship between public debt and economic growth

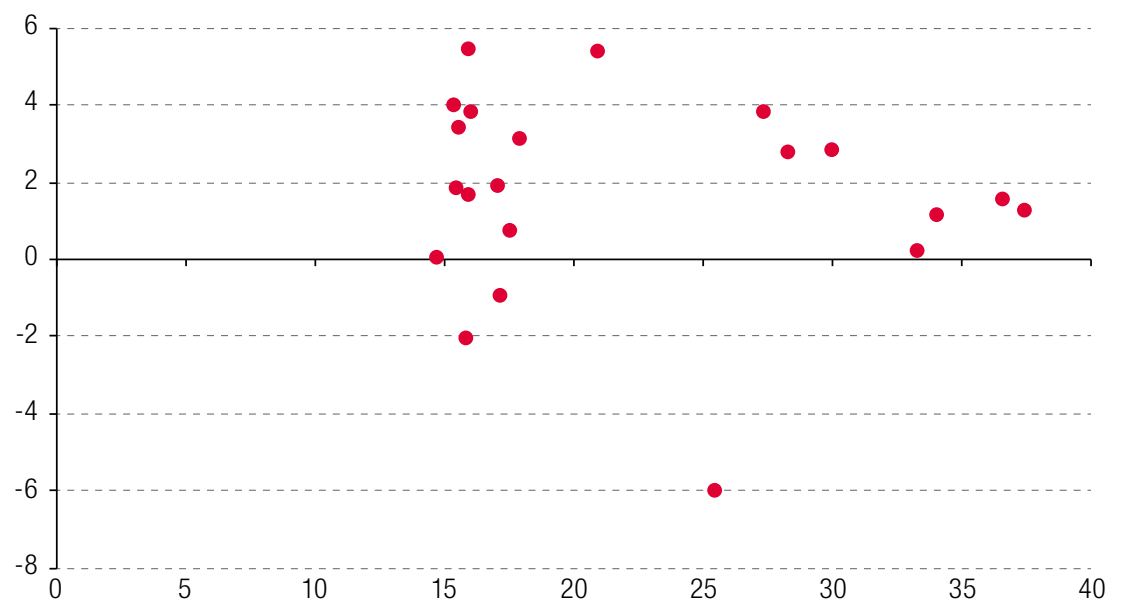

Source: Prepared by the authors, on the basis of data from the National Institute of Statistics and Geography (INEGI). Note: The atypical observation corresponds to 2009, when Mexico was severely affected by the global crisis. 
These results suggest that a quadratic model with econometric tools be used in order to gain insight into elasticity and the inflection point beyond which debt negatively affects marginal growth (according to figure 2, around 20\%-25\%); as well as checking the statistical significance of these results. The goal of this model is to match the results of the empirical evidence with the mechanistic theories of causality, and thus corroborate the resulting conclusions (Maziarz, 2017).

To achieve the objective set out in this document, a simple function was applied, in which per capita GDP is affected by debt. In order to develop the model and set the control variables, a traditional production function approach was used, according to which per capita GDP is a function of physical and human capital and labour input. To quantify this function, we followed the steps set out by Égert (2015) to establish the following proxy variables for each of the independent variables: debt-to-GDP ratio for the debt variable; investment-to-GDP ratio for physical capital; average years of schooling for human capital; and population growth for labour input. The population growth data was obtained from the National Population Council (CONAPO), while the rest of the information was based on INEGI data.

First, an individual analysis was performed to detect the presence of autocorrelation in each of the variables using the identification process from the recursive method of Bartlett (1946). In all of them, both dependent and independent, including control variables, the null hypothesis of no autocorrelation was rejected. However, when obtaining the first difference of each of them and the second difference in the case of average years of schooling, the problem was corrected, and stationary variables were obtained.

A decision was therefore made to implement a dynamic model, in which a delayed endogenous variable is added as part of the explanatory variables. Sánchez-Juárez and García-Almada (2016) assert that this kind of model is appropriate when attempting to explain a variable based largely on past behaviour, which is very helpful in a context in which history plays an important role.

In addition, for the final design of the model, the methodology proposed by Pattillo, Poirson and Ricci (2002) was used as a reference, and natural logarithms were applied to all the variables, except the debt ratio and squared debt ratio, since they would present exact co-linearity problems.

The proposed model was as follows:

$$
\begin{aligned}
& I_{-} G D P c a p_{t}=\beta_{1} D e b t_{-} G D P_{-} 1_{t}+\beta_{2} s q_{-} D e b t_{-} D G P_{-} 1_{t}+\beta_{3} I_{-} D e m G r o w t h \_1_{t} \\
& +\beta_{4} l_{-} I n v_{-} G D P_{-} 1_{t}+\beta_{5} l_{-} E s c \_2_{t}+\beta_{6} l_{-} \text {GDPCap } 1_{t}+\varepsilon_{t}
\end{aligned}
$$

Where $I_{-} G D P c a p_{t}$ is the natural logarithm of per capita GDP in period $t, D e b t_{-} G D P_{-} 1_{t}$ is the first difference of the debt-to-GDP ratio in period $t, s q_{-} D e b t_{-} G D P_{-} 1_{t}$ is the first difference of the square debtto-GDP ratio in period $t, l_{-}$DemGrowth_ $1_{t}$ is the first difference of the natural logarithm of demographic growth in period $t, I_{-} I n v_{-} G D P_{-} 1_{t}$ is the first difference of the natural logarithm of the investment-to-GDP ratio in period $t, L_{-} E s c_{-} 2_{t}$ is the second difference of the natural logarithm of average schooling in period $t$ and $l_{-}$GDPCap $1_{t}$ is the first difference of the natural logarithm of per capita GDP in period $t$.

The results obtained from the econometric analysis are presented in the following section.

\section{Results}

The model proposed in the previous section was implemented. The statistics to evaluate the validity of the model as a whole were favourable, as well as the corresponding evidence of heteroscedasticity, residual normality and autocorrelation. Table 1 shows the results obtained from the coefficients and their statistical significance. 
Table 1

Results of the regression model

Dependent Variable: l_GDPcap

\begin{tabular}{|c|c|c|c|c|}
\hline & Coefficient & Standard Deviation & t Statistic & $\mathrm{p}$ Value \\
\hline Debt_GDP_1 & 1.89473 & 0.745717 & 2.5408 & $0.02261^{* \star}$ \\
\hline$s q \_D e b t \_G D P_{-} 1$ & -3.49558 & 1.47711 & -2.3665 & 0.03184 ** \\
\hline I_DemGrowth_1 & -0.107548 & 0.0765673 & -1.4046 & 0.1805 \\
\hline I_Inv_GDP_1 & -0.0734902 & 0.091145 & -0.8063 & 0.43267 \\
\hline I_EsC_2 & -0.181212 & 0.175181 & -1.0344 & 0.31733 \\
\hline I_GDPcap_1 & 0.963512 & 0.0532298 & 18.101 & $<0.00001^{\star \star \star}$ \\
\hline \multicolumn{5}{|c|}{$F(6,15)=1213218$} \\
\hline \multicolumn{5}{|c|}{ Prob $>F=0.0000$} \\
\hline \multicolumn{5}{|c|}{$R^{\wedge} 2=0.99$} \\
\hline Ho: Absence of heteroscedasticity & & \multicolumn{2}{|c|}{ Prob > chi } & 0.5625 \\
\hline Ho: Error is normally distributed & & \multicolumn{2}{|c|}{ Prob > chi } & 0.2453 \\
\hline Ho: Absence of autocorrelation & & \multicolumn{2}{|c|}{ P-value } & 0.3377 \\
\hline
\end{tabular}

Source: Prepared by the authors.

First, the negative sign of the variable debt-to-GDP ratio squared ( $s q_{-} D e b t_{-} G D P_{-} 1$ ) confirms the quadratic or non-linear relationship, as well as the existence of an upper limit in the inverted U-shaped curve, between public debt accumulation and economic growth. In addition, both this variable and the debt-to-GDP ratio as a linear relationship Debt_GDP_1 are statistically significant. Except for the statistical validity of the first difference of the dependent variable (__GDPcap_1), which shows the correlation of economic growth with its past, none of the other control variables show a p-value below 0.05 . Fortunately, it is not in our interest to use the elasticity coefficients of these parameters.

According to the data, it can be said that initially, when the accumulation of national debt is low and the curve is following an upward path, a 10\% increase in debt as a proportion of GDP allows per capita production to increase, by an average of 0.19 percentage points. However, once the threshold beyond which the curve begins a downward path is passed, a 10\% increase in the debt-to-GDP ratio causes a reduction in GDP of 0.35 percentage points on average.

Having confirmed the existence of the non-linear relationship, the main interest of this document is in determining the threshold beyond which debt ceases to have positive effects on growth and begins to generate marginal decreases in GDP. Another goal is to obtain some idea of the level of debt that could be considered to cause negative economic growth.

It was found that $\frac{\partial D_{\text {Debt }} G D P}{\partial G D P c a p}=0.2707$. This means that, according to the data used in the proposed model, in Mexico the maximum debt-to-GDP ratio beyond which marginal impacts become negative is just over $27 \%$. This does not mean that the country stops growing, but that the accumulation of more debt will cause the economy to grow more slowly. Finally, according to the estimates made, the debt ratio of Mexico would have to reach around $55 \%$ for the economy to stagnate, that is, for the growth rate to be less than $0 \%$.

However, to confirm this result, a decision was made to implement another model with the same characteristics, the only difference being that the variable of schooling was eliminated- annual constant growth had been assumed for this variable due to a lack of official information. This model is also statistically significant as a whole, and does not present any problems of heteroscedasticity, autocorrelation or non-normality in the distribution of residuals.

As shown in table 2, the negative sign of the variable $s q_{-} D e b t_{-} G D P_{-} 1$ reconfirms the existence of the inverted U-shaped curve. In addition, both this variable and Debt_GDP_1 are statistically significant. In this new model, unlike the previous one, the rest of the control variables pass the tests of statistical validity, although the negative sign of investment and demographic growth do not reflect the expected effects on growth based on economic literature. The lagged variable of per capita GDP remains significant and with the expected sign. 
Table 2

Results of the second regression model

Dependent Variable: l_GDPcap

\begin{tabular}{|c|c|c|c|c|}
\hline & Coefficient & Standard Deviation & t Statistic & $\mathrm{p}$ Value \\
\hline Debt_GDP_1 & 2.2804 & 0.719039 & 3.1715 & $0.00558^{* \star *}$ \\
\hline sq_Debt_GDP_1 & -4.5183 & 1.47314 & -3.0671 & $0.00698^{\star \star \star}$ \\
\hline I_DemGrowth_1 & -0.212412 & 0.0667334 & -3.183 & $0.00544^{\star \star \star}$ \\
\hline I_Inv_GDP_1 & -0.149109 & 0.0679229 & -2.1953 & $0.04232^{\star \star}$ \\
\hline I_GDPcap_1 & 0.87819 & 0.0291621 & 30.1141 & $<0.00001^{\star \star *}$ \\
\hline \multicolumn{5}{|c|}{$F(5,17)=1268095$} \\
\hline \multicolumn{5}{|c|}{ Prob $>F=0.0000$} \\
\hline \multicolumn{5}{|c|}{$R^{\wedge} 2=0.99$} \\
\hline Ho: Absence of heteroscedasticity & \multicolumn{3}{|c|}{ Prob > chi } & 0.3494 \\
\hline Ho: Error is normally distributed & \multicolumn{3}{|c|}{ Prob >chi } & 0.3571 \\
\hline Ho: Absence of autocorrelation & \multicolumn{3}{|c|}{ P-value } & 0.0929 \\
\hline
\end{tabular}

Source: Prepared by the authors

Elasticity before and after the inflection point is very similar to that in the previous model: in the rising part, with a 10\% increase in the debt ratio, the per capita GDP increases by an average of 0.23 percentage points, and in the descending part, with the same increase in the debt-to-GDP ratio, per capita product is reduced by 0.45 percentage points.

In this case, the threshold was found to be just over $25 \%$, only 2 percentage points below the level from the previous model. In addition, the level of debt that must be reached to negatively impact the rate of GDP growth is 50\%, also slightly lower than in the previous model. This confirms that the handling of the schooling data did not have a major impact on the results of the model. It is important to note that the levels detected in this document are within the range proposed by Égert (2015), despite being closer to the lower limit than the average.

One of the main causes of this low threshold is considered to be inefficient use of public resources and, therefore, the low productivity of the deficit. In previous paragraphs, data have been presented that reflect the sustained increase in social spending and reduction in capital expenditure in recent years, resulting in a low threshold.

The authorities responsible for planning and implementing Mexico's economic policy should take these figures into account. Although the country's debt is not yet at the worrying levels that endanger national sovereignty previously seen in the late 1980s and mid-1990s, it is important to take appropriate and timely measures to ensure that point is not reached.

It is true that we are facing a very complex macroeconomic environment, with more threats than opportunities, and greater concern over nations' stability than with their growth and development. This is why it is crucial for governments to be involved in economic activity and to provide an incentive through aggregate demand.

However, using debt to support increases in spending and public investment is a questionable strategy that must be analysed in depth, because it can lead a country into a worse situation. This does not mean that debt itself is bad. Rather, as stated in this paper, debt is a powerful instrument to grow and finance productive projects, but a large accumulation of debt can lead to pessimistic sovereign risk expectations and can impact private investment, potentially undoing any progress and even wrecking a modern economy.

Moreover, although it will not change the non-linear relationship, especially in developing countries, resources obtained through a deficit that are channelled into public investment and capital expenditures may shift the threshold in the relationship between debt and growth to the right. This is 
because the expectations and attraction of private investment generate a crowding-in effect. In fact, public spending on public investment and capital expenditures can be a bridge to a more competitive future and greater economic growth.

Now is the time to introduce new models that allow States to remain actively involved in the economy and that stimulate economic growth, but with strategies that allow earnings to be obtained and that are sustainable in the medium to long term, while not undermining the sovereignty of nations.

For instance, we can look for more efficient tax collection mechanisms that better distribute income and wealth, thereby encouraging expansion in aggregate demand through its main variables: consumption, private investment and public spending.

\section{Conclusions}

Despite the difficulty of finding a relationship in the form of an inverted $U$ that represents the effects of public debt on economic growth as mentioned by Égert (2015), this paper was able to demonstrate the existence of this phenomenon in Mexico in the period from 1994 to 2016. The inflection point of the curve was also detected at a debt-to-GDP ratio of $27 \%$. Therefore, beyond this approximate limit, marginal contributions to growth become negative. Moreover, if the debt-to-GDP ratio surpasses a threshold of $55 \%$, there is an expectation of growth rates of close to $0 \%$ or even negative growth.

The 27\% threshold is within the range provided by Égert (2015), despite being very close to the lower limit. Nonetheless it is outside the range proposed by Pattillo, Poirson and Ricci (2002). This raises the question of why Mexico's threshold seems to be below the results found by other authors in other countries.

The most logical answer to this question seems to be that each country has its own limit according to its characteristics, such as private investors' perception of what that limit might be. For example, the probability of sovereign default is much higher in Mexico than in the United States, so its limit will be much lower. Another reason could be the misuse of resources in non-productive activities that do not generate growth, so that debt accumulation reaches a point of divergence faster than in countries where they are properly invested. In the case of Mexico, Sánchez-Juárez and García-Almada (2016) found that federal debt is predominantly used to finance social spending, rather than public investment projects, which would have a direct impact on economic growth by attracting private investment. Such investment can move the threshold in the relationship between debt and growth to the right, increasing the Mexican economy's capacity for indebtedness, and therefore also for growth.

Future research papers should focus on discussing the causes of this limit in Mexico, which seems very low compared to the results for other countries and regions of the world. In addition, calculation of the multipliers for social spending and capital spending in Mexico will be left for future research, to further this discussion and determine what impact can be derived from use of the public deficit in productive activities in Mexico.

\section{Bibliography}

Albarrán, E. (2017), "Gasto público aporta poco al PIB: ASF", El Economista, Mexico City, 1 November. Arestis, P. (2009), "New consensus macroeconomics: a critical appraisal", The Levy Economics Institute Working Paper, No. 564, Cambridge, University of Cambridge.

Aschauer, D. (1989a), "Is public expenditure productive?", Journal of Monetary Economics, vol. 23, No. 2, Amsterdam, Elsevier. 
(1989b), “Does public capital crowd out private capital”, Journal of Monetary Economics, vol. 24, No. 2, Amsterdam, Elsevier.

Bartlett, M. (1946), "On the theoretical specification and sampling properties of autocorrelated time-series", Supplement to the Journal of the Royal Statistical Society, vol. 8, No. 1, Hoboken, Wiley.

Cecchetti, S., M. Mohanty and F. Zampolli (2011), "The real effects of debt", BIS Working Paper, No. 352, Basel, Bank for International Settlements (BIS).

Checherita-Westphal, C. and P. Rother (2012), "The impact of high government debt on economic growth and its channels: an empirical investigation for the euro area", European Economic Review, vol. 56, No. 7 , Amsterdam, Elsevier.

Domínguez, J. (2013), "Deuda pública y crecimiento económico: una relación llena de dudas”, eXtoikos, No. 11, Malaga, Econospérides Institute.

Durán, A. (2018), "En 2017 la inversión pública se desploma 20\%”, El Sol de México, Mexico City, 19 February.

ECLAC (Economic Commission for Latin America and the Caribbean) (2018), Fiscal Panorama of Latin America and the Caribbean, 2018 (LC/PUB.2018/4-P), Santiago.

Égert, B. (2015), "Public debt, economic growth and nonlinear effects: myth or reality?", Journal of Macroeconomics, vol. 43, Amsterdam, Elsevier.

Hatano, T. (2010), "Crowding-in effect of public investment on private investment", Public Policy Review, vol. 6, No. 1, Tokyo, Ministry of Finance.

Herndon, T., M. Ash and R. Pollin (2013), "Does high public debt consistently stifle economic growth? A critique of Reinhart and Rogoff", PERI Working Paper, No. 322, Amherst, University of Massachusetts.

Krugman, P. (2013), "How the case for austerity has crumbled", The New York Review of Books, New York, 6 June.

(2009), "Crowding in", The New York Times, New York, 28 September.

Maziarz, M. (2017), “'Growth in a time of debt' as an example of the logical-positivist science”, The Journal of Philosophical Economics, vol. 10, No. 2, Bucharest, Bucharest Academy of Economic Studies.

Pattillo, C., H. Poirson and L. Ricci (2002), "External Debt and Growth”, Finance \& Development, Washington, D.C., International Monetary Fund (IMF), June.

Reinhart, C. and K. Rogoff (2010), "Growth in a time of debt", American Economic Review, vol. 100, Nashville, American Economic Association.

Roeger, W. and J. Veld (2013), "Expected sovereign defaults and fiscal consolidations", Economic Papers, No. 479, Brussels, European Commission.

Rojas, E. (2017), "Deuda externa de México frena su crecimiento", El Financiero, Mexico City, 3 January.

San Isidoro, R. (2017), “¿Cuáles son los países más endeudados?”, Expansión, Madrid, 22 April.

Sánchez-Juárez, I. and R. García-Almada (2016), "Public debt, public investment and economic growth in Mexico", International Journal of Financial Studies, vol. 4, No. 6, Basel, Multidisciplinary Digital Publishing Institute (MDPI).

Van Wijnbergen, S. (1991a), "Debt relief and economic growth in Mexico", The World Bank Economic Review, vol. 5, No. 3, Washington, D.C., World Bank.

(1991b), "Mexico and the Brady Plan", Economic Policy, vol. 6, No. 12, Oxford University Press. 